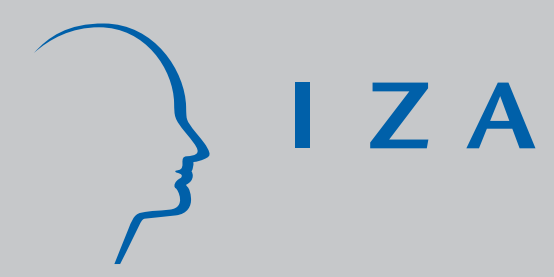

IZA DP No. 1383

Severance Pay and Corporate Finance:

Empirical Evidence from a Panel

of Austrian and Italian Firms

Mirko Cardinale

Mike Orszag

November 2004 


\title{
Severance Pay and Corporate Finance: Empirical Evidence from a Panel of Austrian and Italian Firms
}

\author{
Mirko Cardinale \\ Watson Wyatt LLP \\ Mike Orszag \\ Watson Wyatt LLP \\ and IZA Bonn
}

\section{Discussion Paper No. 1383 \\ November 2004}

\author{
IZA \\ P.O. Box 7240 \\ 53072 Bonn \\ Germany \\ Phone: +49-228-3894-0 \\ Fax: +49-228-3894-180 \\ Email: iza@iza.org
}

\begin{abstract}
Any opinions expressed here are those of the author(s) and not those of the institute. Research disseminated by IZA may include views on policy, but the institute itself takes no institutional policy positions.

The Institute for the Study of Labor (IZA) in Bonn is a local and virtual international research center and a place of communication between science, politics and business. IZA is an independent nonprofit company supported by Deutsche Post World Net. The center is associated with the University of Bonn and offers a stimulating research environment through its research networks, research support, and visitors and doctoral programs. IZA engages in (i) original and internationally competitive research in all fields of labor economics, (ii) development of policy concepts, and (iii) dissemination of research results and concepts to the interested public.
\end{abstract}

IZA Discussion Papers often represent preliminary work and are circulated to encourage discussion. Citation of such a paper should account for its provisional character. A revised version may be available directly from the author. 
IZA Discussion Paper No. 1383

November 2004

\section{ABSTRACT}

\section{Severance Pay and Corporate Finance: Empirical Evidence from a Panel of Austrian and Italian Firms}

This paper examines the empirical link between severance pay and corporate finance. Severance pay is an economic debt of the employer and hence should be taken into account by the market in its assessments of risk. Using a hand collected dataset of accounting data from Italy and Austria we find there is only a limited relationship between severance pay and market risk indicators. This suggests that arguments that severance pay systems destroy corporate value may need to be reassessed.

JEL Classification: J65, J32, G39

Keywords: severance pay, corporate finance, Austrian employee benefits, Italian employee benefits

Corresponding author:

J. Michael Orszag

Watson Wyatt LLP

London Road, Reigate

Surrey RH2 9PQ

United Kingdom

Email: Michael.Orszag@watsonwyatt.com 


\section{Introduction}

Severance pay systems are one of the most pervasive and expensive employee benefits in the world. As such, they are necessarily a significant part of corporate debt and hence corporate finance, yet there is little empirical evidence on the impact of severance pay in the literature. Such systems have been criticised on the grounds they have negative impact on corporate value and economic efficiency yet there has been no effort we are aware of to examine this impact empirically.

There is certainly empirical evidence that the market takes into account other forms of employee benefit liabilities. For example, Bulow et. Al. (1985), Feldstein et. Al. (1985) and Bodie (1985) are among the studies which show that the market does take into account the value of unfunded pension liabilities whereas Carroll-Niehaus (1998) show that pension liabilities affect corporate debt ratings. And, Mittelstaedt and Warshawsky (1993) show that retiree health liabilities of companies affect stock prices. More recently, Jin et al. (2004) show with 1993-1998 US data that CAPM betas reflect risk embedded in companies' pension plans.

This paper reviews how severance pay liabilities can be incorporated in corporate finance models and then looks at evidence on how the market reacts to severance pay liabilities. Severance pay is recorded on the balance sheet of several countries. We focus the empirical analysis in this paper on Italy and Austria because disclosures are of reasonable quality and it has been possible to construct three year panels for both countries.

Severance pay liability analysis has a number of complications. The extent to which individuals draw funds early is a very important consideration. There has been much recent discussion about conversion of severance pay systems into pension funds but this assumes severance pay systems are used for long-term accumulation as opposed to unemployment benefits. For example, the average level of severance pay liabilities to wages in 2002 in Italy is 0.36 which corresponds to about 5 years of accumulations at $1.5 \%$ real wage growth or only $20 \%$ of what would be accumulated over 20 years. The short term nature of these severance funds is an important distinction between other long-term benefits such as pensions and retiree health which have been examined in the literature. 
Severance pay is a debt of the employer and in corporate finance theory debt leads to higher required rates of return and hence higher risk. Risk in financial theory is measured either through beta or volatility. We examine the link between measures of severance pay exposure and both measures. The evidence of a link is quite limited.

The rest of the paper is organised as follows. In Section 2 we review the severance pay systems of Italy and Austria. In Section 3 we review our panel data and calculate various summary measures of severance liability exposure in Italy and Austria. In Section 4 we assess how market volatility and beta are related to various measures of severance pay exposure. A final section concludes.

\section{Severance Pay in Italy and Austria}

\subsection{Severance Pay in Italy}

Severance pay has existed in Italy since 1919 and since 1966 it has been extended to all employees. It is currently regulated by the principles set out in the Law n.297/1982, which introduced the term "trattamento di fine rapporto" (TFR), and in Art. 2120, 2121 and 2776 of the Italian Civil Code. Since 1997 these principles apply also to public sector employees, which were previously subject to a separate regulation.

TFR is essentially a termination indemnity proportional to years of service, which is paid to employees when they leave the firm. Since 1993 (D. LGS. 21 Aprile 1993, N. 124) subsequent Governments have attempted to divert the TFR into second pillar defined contribution pension funds. Since 1996 new employees must earmark the totality of their TFR contributions to a second pillar scheme if they choose to join it, but they are not required to do so. This could now change after the Government in 2004 approved a plan to further boost complementary schemes (Delega al Governo in Materia Previdenziale), which would, among others, make TFR diversion into pension funds the default option as opposed to the current system where an active choice is required.

Law n.297/1982 requires TFR entitlements to be computed in a notional defined contribution fashion with rate of return guarantee and no funding requirement. At present the great majority of TFR liabilities are financed through book reserves, while a small fraction is reinsured. The problem with TFR risk management is 
however there are virtually no financial instruments indexed to Italian inflation rates. In fact the Italian Government, following France, has recently issued $€ 25 \mathrm{bn}$ in inflation-linked bonds, but these are linked to the Euro HICP ex tobacco index and not the Italian CPI.

Gross employer contributions are calculated at the end of the year multiplying each employee's salary by factor of $1 / 13.5$, but $0.5 \%$ of contributions are diverted to the social security administrative body INPS, which runs a TFR guarantee fund, thus giving a net contribution of $6.91 \%$ of salary. Salaries are taken excluding exceptional payments, the exact definition of which is left to collective agreements regulating the Italian labour market.

To compute TFR entitlements, past contributions are revalued at a gross rate of $1.5 \%$ plus $75 \%$ of consumer price inflation recorded by ISTAT and measured since the previous December. Revaluations are then subject to an $11 \%$ flat tax rate. After completing 8 years of service employees are allowed to draw down their TFR account to fund medical expenses or to purchase the first home for themselves or their sons. There are however limits to the amounts which can be withdrawn, set out at individual (not over $70 \%$ of the account) and firmwide level (only 10\% of employees with over 8 years of service and $4 \%$ of total employees are allowed each year to make withdrawals).

The value of each employee individual account at the end of each year is therefore calculated by adding up present contributions $(6.91 \%$ of salary) and past contributions revalued at the interest rate mandated by law, and subtracting withdrawals. Aggregate TFR liabilities reported in company accounts are simply worked out by summing up the values of all individual positions.

This methodology is clearly in contrast with the principles set out in IAS 19 (in particular art. 132-143) on the evaluation of deferred compensation schemes, which, under the proposals of the European Commission, will have to be adopted by 2005 by all Italian listed companies.

As explained in Micocci (2001), TFR liabilities under IAS 19 will have to be projected taking into account:

- Date of leaving the firm, which could be due to retirement, voluntary departure, dismissal etc. 
- Probability of withdrawals

- Future salary growth

- Future inflation, because TFR revaluations are indexed to consumer price inflation

- Discount rate

Micocci (2001) use the following assumptions to illustrate the impact of IAS 19: inflation rate $(2 \%$, which gives a $3 \%$ TFR revaluation rate), nominal salary growth ( $2.5 \%$ plus $1.5 \%$ for males and $1 \%$ for females), discount rate $(5 \%)$, probability of withdrawal (10\%), probability of voluntary leave (10\%).

More details about the Italian severance pay system are in Watson Wyatt (2004a) and Watson Wyatt (2004b).

\subsection{Severance Pay in Austria}

The Austrian severance pay system has undergone a radical overhaul following the introduction of a new individual accounts-type of system for all new employment contracts after 1 January, 2003. The old system (Abfertigung) was regulated by the 1921 Salary Earners Act (Angestelltengesetz) and the 1979 Wage Earners' Severance Pay Act (Arbeiterabfertigungsgesetz). Unlike in Italy where any employment termination results in severance pay entitlements, in the old Austrian system employees were entitled to severance pay under specific circumstances: in case of dismissal (except summary termination) after more than 3 years of service ${ }^{1}$, voluntary termination after more than 10 years of service or in special circumstances such as childcare or birth.

The severance pay entitlement under the old system is calculated as multiple of salary and is in function of length of service (for instance 2 x salary after 3 years and up to $12 \mathrm{x}$ salary after 25 years). Severance pay under the old system also gives rise to benefits to survivors: half of severance pay is paid out to survivors in case of death of an employee. Severance pay under the pre-2003 system comes almost free of deductions: only $6 \%$ is taxed.

Under the new system, $1.53 \%$ of monthly salary is transferred to a severance pay fund and invested in the capital markets by ad-hoc institutions (MVKs). All

\footnotetext{
${ }^{1}$ With the exception of construction workers who are entitled to severance pay after only 92 weeks of service and not necessarily with one employer
} 
employees are enrolled in the system and upon termination they can choose whether to take out their entitlements or to transfer to the MVK with which the worker's new employer has a contract.

Most Austrian companies report under international accounting standards (in general IAS), which ensure consistency with the guidelines in IAS 19 for employees' benefit programmes with a defined benefit component: liabilities arising from the old severance pay system are calculated as projected benefit obligations and the notes disclose the main assumptions (discount rate, salary growth etc.).

\section{Overview of the Data}

We collected 3 years of company accounts for over 30 of the largest Austrian companies and more than 90 of the largest Italian companies. For the accounting year 2003 and using index weightings as of October 2004, Austrian companies in the panel represent $89 \%$ of the Wiener Börse Share Index and Italian companies represent $74 \%$ of the Mibtel, the broadest index of Milan-listed shares.

From company accounts or Bloomberg we collected key company financials metrics (e.g. revenue, long term debt, market capitalisation at the reporting date etc.), employee data and all the available information on severance pay programmes. The severance pay data collection template used was different for Italy and Austria due to differences in reporting standards highlighted in section 2 and 3. For instance, items related to actuarial assumptions and movements in the severance pay projected benefit obligation are only available for Austrian companies. There is also a clear difference in how severance pay liabilities are calculated in Austria, which is in line with IAS 19 guidelines, and the methodology used in Italy which does not allow for projected salary increase nor discount expected future cash flows.

The Italian and Austrian panels were then matched to data on beta, stock market volatility at different horizons (from 10 days to 162 weeks) from Bloomberg as well as to credit ratings from Standard \& Poor's. The Austrian panel was matched on October 4, 2004 and the Italian panel on October 13, 2004.

The total market capitalisation of the 35 Austrian companies for which annual reports published between the second half of 2003 and the first half of 2004 were available was equal to $€ 48.3 \mathrm{bn}$ as of October 4, 2004, compared to $€ 36.4 \mathrm{bn}$ at the 
latest reporting date ${ }^{2}$. The total market capitalisation of the 98 Italian companies with reports published in either the second half of 2003 or the first half of 2004 is $€ 458 \mathrm{~m}$ as of October $13,2004^{3}$ against $€ 407 \mathrm{~m}$ for the 92 companies with market capitalisation available at the latest reporting date.

As of October 4, 2004 the median market cap among the Austrian companies is $€ 604 \mathrm{~m}$ but there is a high degree of concentration with the top 3 companies (Bank Austria Creditanstalt, Erste Bank and Telekom Austria) representing 46\% of the total. Among the Italian companies the median market cap as of October 13, 2004 is $€ 1,291 \mathrm{~m}$ and the largest 5 companies (Eni, Enel, TIM, Telecom Italia and Assicurazioni Generali) account for $48 \%$ of the aggregate.

In both countries most of the accounting dates were December, 31: only 6 Austrian companies and 4 Italian companies reported at different dates in 2003 or 2004. To construct the panel, companies reporting between June of a given year and May of the following year were assigned to a common wave of observations (for example the 2003 wave comprises companies reporting between June 2003 and May 2004). As discussed in section 2 and 3, accounting standard differ in the two countries: in Austria 32 out of 35 companies in the 2003 wave reported under international accounting standards (4 under US GAAP, the rest under IAS/IFRS), while in Italy 89 companies in 2003 still reported under domestic standards.

Among the 35 Austrian companies in wave 2003, the industry composition is fairly widespread but with a prevalence of traditional sectors (there are 17 between industrial, energy and basic materials companies). Among the 98 Italian companies for which the latest reports are available, 31 are financial, 27 from various consumer goods sector, 17 industrial, 9 communication, 7 between energy and basic materials and finally 6 are utilities ${ }^{4}$. Table 4.1 reports the industry composition for Austrian and Italian companies with available accounts published in either the second half of 2003 or the first half of 2004.

\footnotetext{
${ }^{2}$ The market cap as of October 4, 2004 is not available for one reporting company (Constantia Iso). Market cap is taken as of $31 / 12$ of each year

${ }^{3}$ Market cap as of October 13, 2004 is not available for 2 of the reporting companies: Saeco and Saiag

${ }^{4}$ One company (IFI, one of FIAT's holding companies) is classified as Diversified
} 
Table 4.1: Industry composition of the Italian and Austrian panel

\begin{tabular}{|c|c|c|c|}
\hline \multicolumn{4}{|c|}{ Austria } \\
\hline Industry & 2001 & 2002 & 2003 \\
\hline Basic Materials & 4 & 4 & 4 \\
\hline Communications & 2 & 1 & 1 \\
\hline Consumer, Cyclical & 6 & 6 & 4 \\
\hline $\begin{array}{c}\text { Consumer, Non- } \\
\text { cyclical }\end{array}$ & 4 & 4 & 2 \\
\hline Energy & 2 & 2 & 2 \\
\hline Financial & 5 & 6 & 6 \\
\hline Industrial & 10 & 11 & 11 \\
\hline Technology & 3 & 3 & 3 \\
\hline Utilities & 2 & 2 & 2 \\
\hline Total & 38 & 39 & 35 \\
\hline \multicolumn{2}{|c|}{ Italy } & & \\
\hline Industry & 2001 & 2002 & 2003 \\
\hline Basic Materials & 4 & 5 & 4 \\
\hline Communications & 9 & 9 & 9 \\
\hline Consumer, Cyclical & 19 & 22 & 20 \\
\hline Consumer, Non- & & & \\
cyclical & 7 & 7 & 7 \\
\hline Diversified & 1 & 2 & 1 \\
\hline Energy & 3 & 3 & 3 \\
\hline Financial & 30 & 31 & 31 \\
\hline Industrial & 16 & 16 & 17 \\
\hline Utilities & 6 & 7 & 6 \\
\hline Total & 95 & 102 & 98 \\
\hline
\end{tabular}

Both in Austria and Italy there is a high degree of variation in the labour intensiveness of companies' production processes. In both countries firms in traditional sectors such as Basic Materials or Industrials are characterised by a higher wage to market cap ratio compared to for instance financial companies or utilities. Table 4.2 shows the distribution of the total wage bill, number of employees, wage bill to market cap ratio and wage per employee in the two countries as of the latest reporting date. 
Table 4.2: Labour force statistics for the Italian and Austrian panel

\begin{tabular}{|c|c|c|c|c|c|}
\hline \multicolumn{5}{|c|}{ Austria (2003 wave) } \\
\hline Variable & Obs. & Mean & $\begin{array}{c}10^{\text {th }} \\
\text { Percent }\end{array}$ & Median & $90^{\text {th }}$ Percent \\
\hline $\begin{array}{c}\text { Total Wage } \\
\text { Bill }\end{array}$ & 30 & $€ 229 \mathrm{~m}$ & $€ 18 \mathrm{~m}$ & $€ 146 \mathrm{~m}$ & $€ 671 \mathrm{~m}$ \\
\hline $\begin{array}{c}\text { Number of } \\
\text { Employees }\end{array}$ & 34 & 7,117 & 415 & 3,906 & 17,478 \\
\hline $\begin{array}{c}\text { Wage Bill to } \\
\text { Market Cap } \\
\text { Ratio }\end{array}$ & 30 & $47.92 \%$ & $10.04 \%$ & $24.84 \%$ & $119.50 \%$ \\
\hline $\begin{array}{c}\text { Wage Bill } \\
\text { per } \\
\text { Employee }\end{array}$ & 30 & $€ 33,599$ & $€ 16,523$ & $€ 32,106$ & $€ 55,230$ \\
\hline $\begin{array}{c}\text { Total Wage } \\
\text { Bill }\end{array}$ & 90 & $€ 389$ & $€ 9$ & $€ 87$ & $€ 1,260$ \\
\hline $\begin{array}{c}\text { Number of } \\
\text { Employees }\end{array}$ & 95 & 12,005 & 398 & 2,484 & 36,558 \\
\hline $\begin{array}{c}\text { Wage Bill to } \\
\text { Market Cap } \\
\text { Ratio }\end{array}$ & 84 & $19.39 \%$ & $1.67 \%$ & $11.25 \%$ & $43.73 \%$ \\
\hline $\begin{array}{c}\text { Wage Bill } \\
\text { per } \\
\text { Employee }\end{array}$ & 88 & $€ 43,342$ & $€ 17,662$ & $€ 31,580$ & $€ 51,165$ \\
\hline
\end{tabular}

Notes:

1. Holding company IFI excluded from the Italian sample (wage bill and number of employees would represent a double counting of FIAT)

The total wage bill is less than $€ 100 \mathrm{~m}$ for the median Italian company but the average is driven up by a few large companies such as FIAT and national carrier Alitalia and other such as the football club Juventus. With respect to Italy in Austria there is a smaller proportion of both very small and very large companies in terms of both total wage bill and number of employees. For the median Austrian company the wage bill represent a higher proportion of market capitalisation $(25 \%$ as opposed to $11 \%$ for the median Italian company). Finally wages per capita levels for the median company are not very different in the two countries, but the average for Italy is driven up by a few observations such as Juventus and investment bank Mediobanca.

In both Austria and Italy only a small proportion of companies are rated by Standard \& Poor's and this is not surprising given the high proportion of small companies in Italy and the traditional reliance on bank financing as opposed to capital markets in both countries. Table 4.3 shows S\&P local issuer long term ratings as of 
October 2004 for Italian and Austrian companies. 67\% of Italian and 80\% of Austrian companies are currently not rated.

Table 4.2: S\&P-local issuer long term credit ratings of Italian and Austrian companies

$\begin{array}{ccc}\begin{array}{c}\text { S\&P } \\ \text { Rating }\end{array} & \begin{array}{c}\text { N. of } \\ \text { Italian } \\ \text { companies }\end{array} & \begin{array}{c}\text { N. of } \\ \text { Austrian } \\ \text { companies }\end{array} \\ \text { AA } & 3 & 0 \\ \text { AA- } & 3 & 0 \\ \text { A+ } & 4 & 1 \\ \text { A } & 3 & 2 \\ \text { A- } & 5 & 1 \\ \text { BBB+ } & 3 & 0 \\ \text { BBB } & 5 & 2 \\ \text { BBB- } & 2 & 0 \\ \text { BB- } & 2 & 0 \\ \text { B+ } & 2 & 1 \\ \text { WR } & 0 & 1 \\ \text { NR } & 66 & 27\end{array}$

Notes:

1. WR stands for Withheld Rating

For rated companies an S\&P synthetic outlook (positive, negative, stable) is also available. In Austria 5 of the seven rated companies have a stable outlook, 1 positive and 1 negative, while in Italy 21 have a stable outlook, 7 negative and only 2 positive.

The distribution of market beta and volatility across the two samples are presented in the following charts. Volatility data are available for different frequencies, but the focus here is on the long-term end of the spectrum. Figure 4.1 presents the distribution of 360-day volatility and market beta in the two countries and Table 4.2 reports the highest values in the sample for both stock-specific risk measured by both beta and volatility. Interestingly none of the highest beta companies are also highest in terms of volatility and the overall correlation between beta and 360-days volatility is just over $20 \%$ in both countries. 
Figure 4.1: Distribution of Market Beta and Volatility by Country
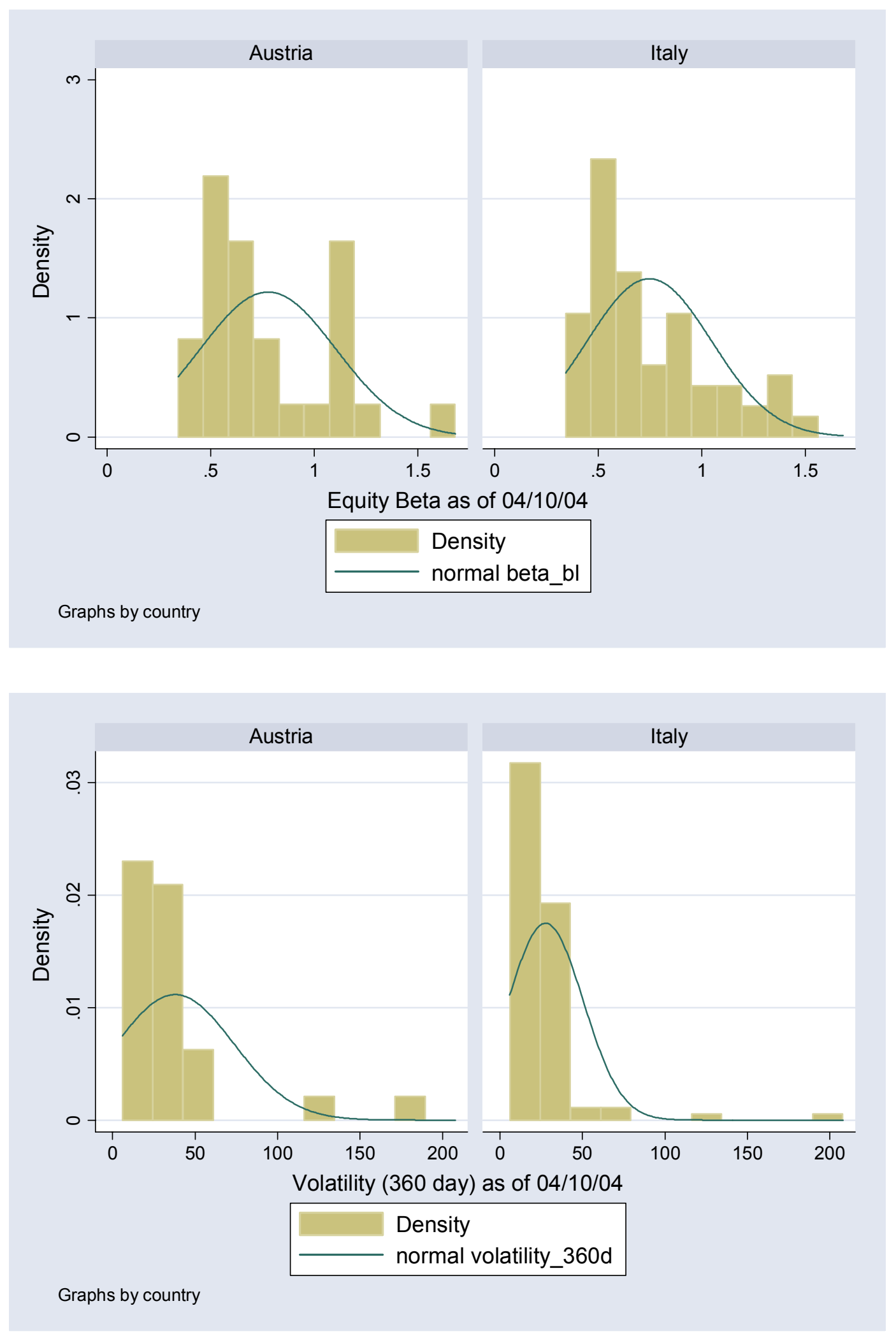
Table 4.2: Companies with highest beta and volatility in the sample

Volatility (1-year) higher than 100

\section{Company}

Erste Bank

Generali Holding Vienna

Fineco Group

Gruppo Ceramiche Ricchetti

Market Beta higher than 1.4

\section{Country Industry}

Austria Financial

Austria Financial

Italy Financial

Italy Industrial
Volatility

120.26

178.489

207.943

120.433
Company

Jowood

Bulgari

Capitalia

Sanpaolo IMI

$\begin{array}{llr}\text { Country } & \text { Industry } & \text { Beta } \\ \text { Austria } & \text { Technology } & 1.682 \\ \text { Italy } & \text { Communications } & 1.483 \\ \text { Italy } & \text { Financial } & 1.484 \\ \text { Italy } & \text { Financial } & 1.402\end{array}$

\section{Severance Pay Exposure Indicators}

This section looks at the distribution of key indicators of severance pay exposure across the sample. These are divided into capital structure leverage-based measures and net periodic cost-based indicators. Assumptions to calculate the projected benefit obligation are also analysed for Austria to investigate the extent to which data are comparable across companies.

\subsection{Balance Sheet Exposure}

Severance pay liabilities data are available for most Austrian and Italian companies in (31 Austrian companies and all of the 98 Italian companies). However, full disclosure of projected benefit obligation for Austrian companies is not always available because in some cases the reconciliation was not presented separately for severance pay liabilities but aggregated with other long-term benefits such as pensions and contractual termination indemnities. This is for instance the case of OMV which reports a $€ 97 \mathrm{~m}$ severance pay liability and a $€ 373 \mathrm{~m}$ aggregate projected benefit obligation. In other cases, although the PBO does not include any voluntary severance pay programmes included in the liability ${ }^{5}$, the observations were left in the

\footnotetext{
${ }^{5}$ This is only an issue for one company, Telekom Austria, which operate a voluntary severance pay programme
} 
sample. Full PBO reconciliation was available for 15 Austrian companies in wave 2003.

The following indicators were considered to assess the balance sheet exposure related to severance pay programmes:

- Leverage - Long Term Debt divided by Market Cap

- $\mathrm{BS} 1$ - ratio of severance pay liabilities to market cap (reporting date)

- $\mathrm{BS} 2$ - ratio of severance pay liabilities to market cap (market cap measured in October 2004)

- $\mathrm{BS} 3$ - ratio of severance pay liability to long term debt

- BS4 - ratio of severance pay liability to enterprise value (market cap + long term debt)

- BS5 (only Austria) - ratio of severance pay projected benefit obligation (excludes unrecognised obligations) to market cap

Table 5.1: Balance Sheet Median Exposure by Wave

\begin{tabular}{ccccccc}
\multicolumn{7}{c}{ Austria } \\
2001 & Leverage & BS1 & BS2 & BS3 & BS4 & BS5 \\
2002 & $48.75 \%$ & $4.61 \%$ & $3.68 \%$ & $20.53 \%$ & $3.24 \%$ & $5.02 \%$ \\
2003 & $52.72 \%$ & $6.90 \%$ & $4.32 \%$ & $18.54 \%$ & $4.38 \%$ & $6.88 \%$ \\
& & $5.30 \%$ & $4.85 \%$ & $15.06 \%$ & $4.33 \%$ & $5.45 \%$ \\
2001 & $31.26 \%$ & $4.39 \%$ & $3.34 \%$ & $9.09 \%$ & $2.67 \%$ & n.a. \\
2002 & $45.55 \%$ & $4.69 \%$ & $3.79 \%$ & $9.22 \%$ & $2.30 \%$ & n.a. \\
2003 & $48.50 \%$ & $3.82 \%$ & $3.43 \%$ & $10.13 \%$ & $2.07 \%$ & n.a.
\end{tabular}

For the median Austrian company severance liabilities represented around 5\% of market cap as of 2003 and 4\% for the median Italian company, bearing in mind that the discrepancy could be due to different accounting rules in the two countries. In Austria the ratio is also recalculated using the projected benefit obligation which removes the impact of unrecognised components. Although the value of the BS5 ratio was only available for 15 companies, the median is not very different from BS1 indicating that the impact of unrecognised components is not very large. Interestingly, the ratio of severance pay liabilities over long-term debt is substantially higher in 
Austria (15\% against $10 \%$ in Italy), which makes severance pay liabilities look comparatively smaller in Italy if enterprise value is the term of comparison.

The following charts show the full distribution of BS1 and BS4 for Italian and Austrian companies in wave 2003 and Table 5.2 identify the outliers. As shown in the Table, although severance pay exposure is not very high for the median company, there are labour-intensive firms such as airlines and FIAT where the ratio of severance liabilities to market cap is higher than $20 \%$. However, because debt financing is very important in both countries, the picture changes slightly if enterprise value is the term of comparison (Austrian Airlines and FIAT have both BS4 ratios below 10\%).

Figure 5.1: Distribution of BS1 and BS4 ratios by Country (wave 2003)

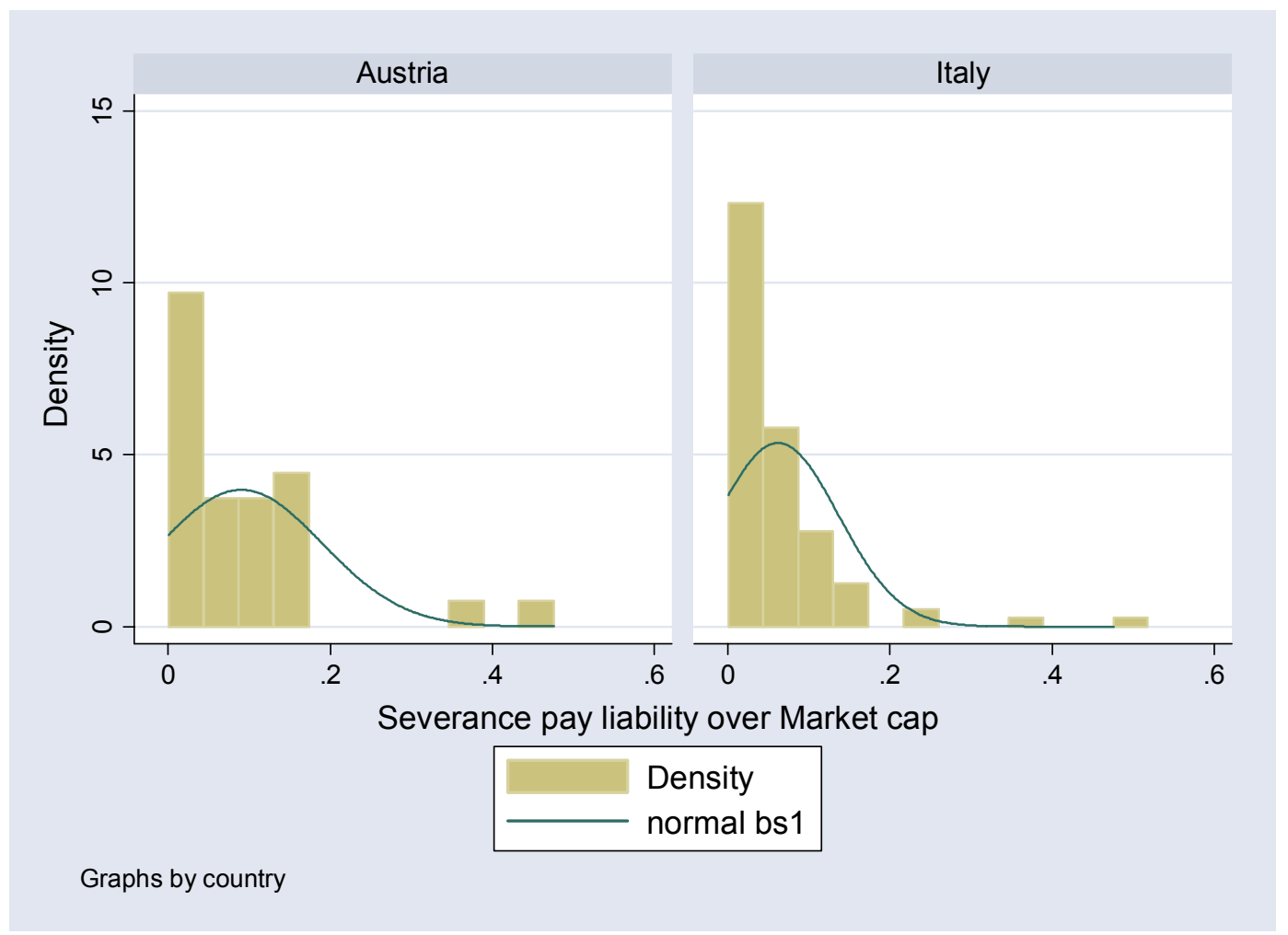




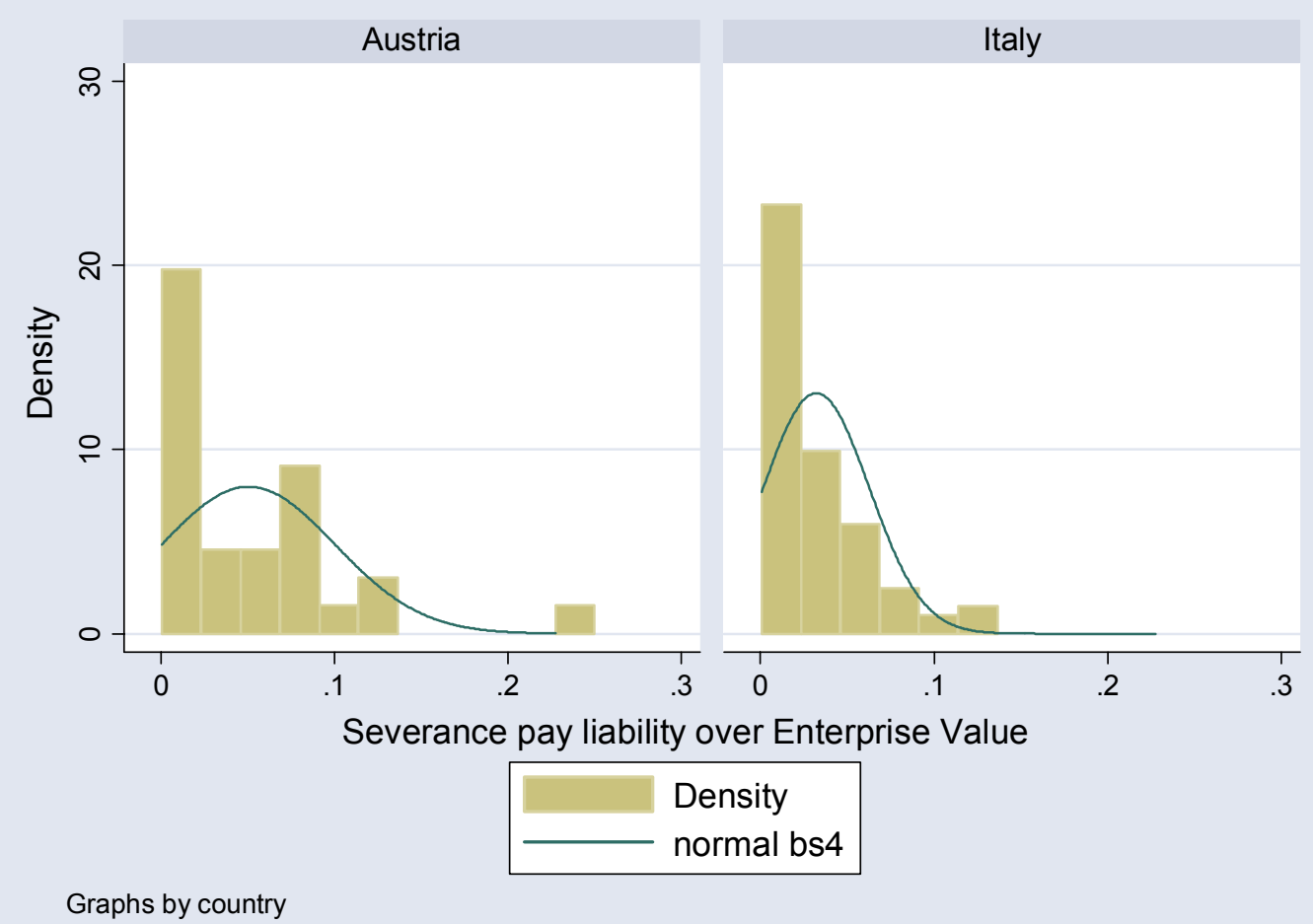

Table 5.2: Companies with highest values of BS1 and BS4 ratios (2003 wave)

BS1 (Severance Liability to Market Cap) higher than 20\%

Company

Austrian Airlines

Va Technologie

Alitalia

Fiat

Ifil

Gruppo Ceramiche Ricchetti

\section{Country}

Austria

Austria

Italy

Italy

Italy

Italy
Industry

Consumer, Cyclical

Industrial

Consumer, Cyclical

Consumer, Cyclical

Diversified

Industrial
BS1

$37.80 \%$

$44.91 \%$

$36.99 \%$

$21.95 \%$

$47.57 \%$

$24.36 \%$

BS4 (Severance Liability to Enterprise Value) higher than 10\%

$\begin{array}{cccc}\text { Company } & \text { Country } & \text { Industry } & \text { BS4 } \\ \text { Miba } & \text { Austria } & \text { Consumer, Cyclical } & 10.44 \% \\ \text { Rosenbauer International } & \text { Austria } & \text { Consumer, Cyclical } & 12.49 \% \\ \text { Va Technologie } & \text { Austria } & \text { Industrial } & 22.73 \% \\ \text { Voestalpine } & \text { Austria } & \text { Basic Materials } & 11.57 \% \\ \text { Alitalia } & \text { Italy } & \text { Consumer, Cyclical } & 13.49 \% \\ \text { Gabetti Holding } & \text { Italy } & \text { Financial } & 11.13 \% \\ \text { Pininfarina } & \text { Italy } & \text { Consumer, Cyclical } & 11.87 \% \\ \text { Gruppo Ceramiche } & \text { Italy } & \text { Industrial } & 12.89 \% \\ \text { Ricchetti } & & & \end{array}$




\subsection{Income Statement Exposure \& Movement in Provisions}

The total severance pay charge to the income statement is available for 90 Italian companies in wave 2003. For 85 companies there is also a reconciliation of movements in severance pay provisions with accruals and use of provisions. In most cases severance pay accruals coincided with reported severance pay cost in the income statement.

In Austria severance pay cost is split in different components (change in measurement unit, current service cost, interest cost, actuarial loss and curtailment loss), similarly to the net periodic pension cost breakdown of defined benefit schemes. A total cost measure was worked out by aggregating all components. Severance pay cost is recorded for 22 companies in 2003, one of which (Telekom Austria) comes out as a negative number due to actuarial gains. Actual benefits paid are also reported as part of the reconciliation of the projected benefit obligation.

The analysis will focus on the following indicators which relate the cost of severance pay programmes or severance benefits paid is related to firms' turnover, wages and personnel costs

- PL1 - ratio of severance pay cost to revenue

- PL2 - ratio of use of provisions (benefits paid in Austria) to revenue

- PL3 - ratio of severance pay cost over wages

- PL4 - ratio of severance pay cost over personnel cost

- PL5 - ratio of severance pay service cost to revenue (for Austria only)

- PL6 - ratio of severance pay interest cost to revenue (for Austria only) 
Table 5.3: Severance Pay Cost Median Exposure by Wave

\begin{tabular}{ccccccc}
\multicolumn{7}{c}{ Austria } \\
2001 & PL1 & PL2 & PL3 & PL4 & PL5 & PL6 \\
2002 & $0.37 \%$ & $0.20 \%$ & $2.18 \%$ & $1.78 \%$ & $0.17 \%$ & $0.17 \%$ \\
2003 & $0.20 \%$ & $0.20 \%$ & $2.85 \%$ & $2.18 \%$ & $0.18 \%$ & $0.18 \%$ \\
& & $0.25 \%$ & $2.10 \%$ & $1.11 \%$ & $0.15 \%$ & $0.19 \%$ \\
2001 & $0.63 \%$ & $0.53 \%$ & $6.03 \%$ & $4.15 \%$ & n.a. & n.a. \\
2002 & $0.68 \%$ & $0.49 \%$ & $6.04 \%$ & $4.35 \%$ & n.a. & n.a. \\
2003 & $0.62 \%$ & $0.47 \%$ & $6.25 \%$ & $4.37 \%$ & n.a. & n.a.
\end{tabular}

Whilst there is not a huge difference across countries if severance pay cost is compared to revenues, severance pay represents a much larger proportion of the wage bill and personnel cost in Italy with respect to Austria (the median of PL3 and PL4 is 3 times higher). This is because the Italian severance pay system is mandatory and severance pay is in most cases the main long-term employee benefit programme for Italian companies $^{6}$. Conversely, in both countries the median of PL1 not too far from the median of PL2, the latter of which is calculated taking into account actual benefits paid as opposed to accounting costs.

Figure 5.2 shows the distribution of PL1 in the two countries and Table 5.4 identifies the outliers.

Figure 5.2: Distribution of PL1 ratio by Country (wave 2003)

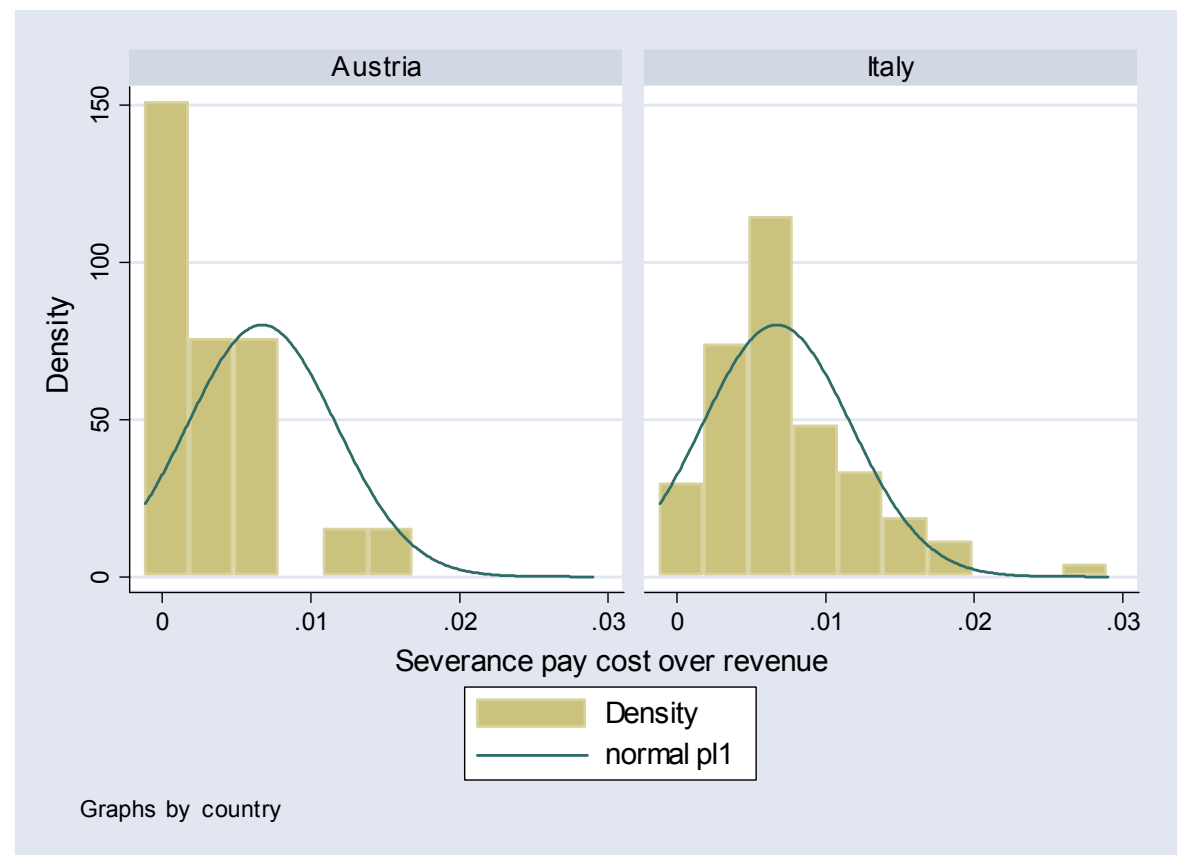


Table 5.4: Companies with PL1 ratio over 1.5\% (2003 wave)

\section{Company Country Industry PL1}

Flughafen Wien Austria Industrial $\quad 1.59 \%$

Aeroporto di

$\begin{array}{llll}\text { Firenze } & \text { Italy } & \text { Industrial } & 1.99 \% \\ \text { Credito Emiliano } & \text { Italy } & \text { Financial } & 1.55 \% \\ \text { Gabetti Holding } & \text { Italy } & \text { Financial } & 1.94 \% \\ \text { Mirato } & \text { Italy } & \text { Consumer, } & 1.83 \%\end{array}$

There are 4 Italian and 1 Austrian company where severance pay costs represent over 1.5\%, among which 2 airports (Flughafen Wien and Aeroporto di Firenze).

\subsection{Labour Market Severance Pay Indicators}

This section relates severance pay to the overall structure of the workforce and compares severance pay liability with the wage bill and the headcount.

In particular 2 are the indicators considered in this context:

- $\quad$ LM1 - ratio of severance pay liability to wage bill

- $\mathrm{LM} 2$ - severance pay liability per employee $(€)$

Figure 5.3 shows the distribution of the two indicators in the two countries and Table 5.5 identifies the outliers.

${ }^{6}$ Defined benefit pensions are virtually non-existent in Italy with the exception of some of the banks. 
Figure 5.3: Distribution of Labour Market Severance Indicators by Country (wave 2003)
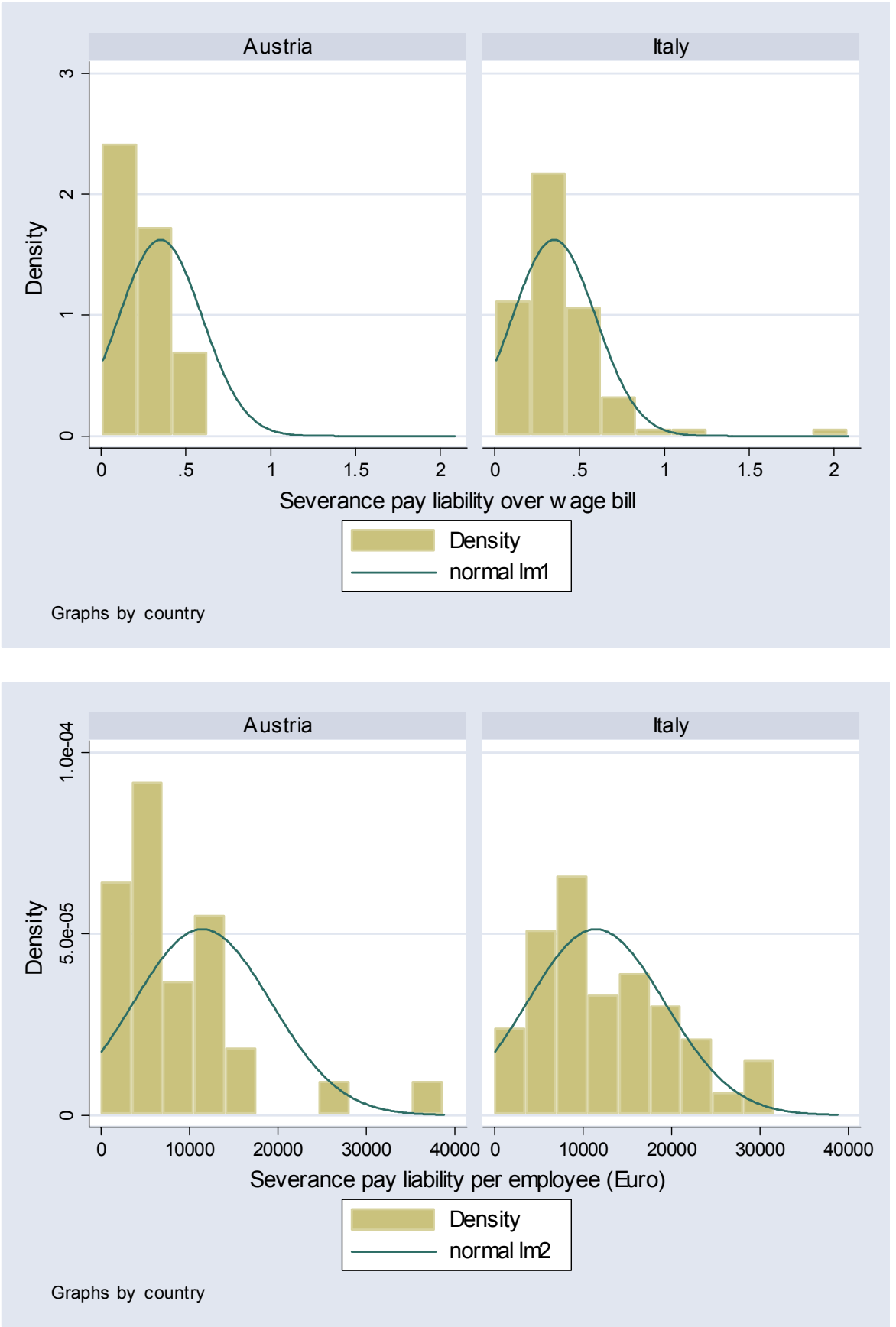

Table 5.5: Companies with highest values of LM1 and LM2 ratios (2003 wave)

LM1 (Severance Pay Liability over Wage Bill) higher than 80\%

\begin{tabular}{lllr}
\multicolumn{1}{c}{ Company } & Country & \multicolumn{1}{c}{ Industry } & LM1 \\
Lottomatica & Italy & Consumer, Cyclical & $208.54 \%$ \\
Montefibre & Italy & Basic Materials & $91.91 \%$ \\
Seat Pagine Gialle & Italy & Communications & $107.30 \%$
\end{tabular}


LM2 (Severance Pay Liability per Employee) higher than €30,000

$\begin{array}{lccc}\quad \text { Company } & \text { Country } & \text { Industry } & \text { LM2 } \\ \text { Verbund } & \text { Austria } & \text { Utilities } & € 38,769 \\ \text { Capitalia } & \text { Italy } & \text { Financial } & € 30,188\end{array}$

For the median Austrian and Italian company severance liabilities account for slightly less than $20 \%$ of the wage bill as opposed to $31 \%$ for the median Italian company. Severance liabilities per employee are around $€ 5,000$ for the median Austrian company and in the range of $€ 10,000$ for the median Italian company. Within each country the two ratios could be interpreted as proxies for maturity of the workforce in terms of age and tenure.

\subsection{Assumptions (Austrian panel)}

In Austria where severance liabilities are calculated as projected benefit obligations, companies report actuarial assumptions on discount rates and salary increases, which form the basis of the liability calculation. Table 5.6 report the distribution across the sample for the three waves of accounting years. In line with IAS recommendations, the median discount rate seem to be in line with yields on highly rated bonds and variations across companies are not very large: the difference between $10^{\text {th }}$ and $90^{\text {th }}$ percentile is less than $1 \%$ in all of the 3 waves. Even salary increase assumptions do not vary too widely, but in 2003 the difference between $10^{\text {th }}$ and $90^{\text {th }}$ percentile has increased to almost $1 \%$. 
Table 5.6: Distribution of actuarial assumptions in Austria (2003 wave)

\begin{tabular}{|c|c|c|c|c|c|}
\hline \multicolumn{7}{|c|}{ 2001 wave } \\
\hline Variable & Obs. & Mean & $\begin{array}{c}10^{\text {th }} \\
\text { Percent }\end{array}$ & Median & $90^{\text {th }}$ Percent \\
\hline $\begin{array}{c}\text { Discount } \\
\text { Rate }\end{array}$ & 35 & 5.31 & 4.00 & 5.50 & 6.00 \\
\hline $\begin{array}{c}\text { Salary } \\
\text { Increase }\end{array}$ & 28 & 2.92 & 2.00 & 3.00 & 3.75 \\
\hline \multicolumn{6}{|c|}{$\mathbf{2 0 0 2}$ wave } \\
\hline $\begin{array}{c}\text { Discount } \\
\text { Rate }\end{array}$ & 36 & 5.31 & 4.25 & 5.5 & 6 \\
\hline $\begin{array}{c}\text { Salary } \\
\text { Increase }\end{array}$ & 31 & 2.91 & 2 & 3 & 3.6 \\
\hline $\begin{array}{c}\text { Discount } \\
\text { Rate }\end{array}$ & 32 & 5.20 & 4.5 & 5.25 & 5.75 \\
\hline $\begin{array}{c}\text { Salary } \\
\text { Increase }\end{array}$ & 29 & 2.93 & 2 & 3 & 3.85 \\
\hline
\end{tabular}

\section{Econometric Analysis of Volatility and Beta}

This section explores the pattern of association between stock market-based measures of risk (volatility and beta) and leverage associated with severance pay programmes. Similarly to other liabilities, severance pay provisions are expected to be recognised by the market as an additional source of leverage and leverage is expected to be positively associated with volatility (Modigliani and Miller, 1958). At the same time, the cost of providing severance pay programmes as a proportion of revenue is also expected to be recognised by the market as a source of leverage similarly to other fixed operating costs.

\subsection{Correlation between indicators}

Given that all indicators defined in the previous section measure the relative exposure of the operating business of Italian and Austrian companies' to severance pay programmes, one would expect a fairly high correlation across them. A correlation matrix showing the pattern of association across indicators in the Italian 2003 sample is shown in the following table. For Austria the number of observations is too small to calculate correlations in the 2003 sample and therefore the 3 waves are pooled together, which means that correlations are measured on a small number of companies 
Table 6.1: Correlation between severance pay indicators

AUSTRIA (2001-2003 sample pooled, obs. 41)

$\begin{array}{lcccccccccc} & \text { BS1 } & \text { BS2 } & \text { BS3 } & \text { BS4 } & \text { PL1 } & \text { PL2 } & \text { PL3 } & \text { PL4 } & \text { LM1 } & \text { LM2 } \\ \text { BS1 } & 100 \% & & & & & & & & & \\ \text { BS2 } & 72.7 \% & 100 \% & & & & & & & \\ \text { BS3 } & -5.3 \% & -8.4 \% & 100 \% & & & & & & \\ \text { BS4 } & 60.7 \% & 54.0 \% & 11.7 \% & 100 \% & & & & & \\ \text { PL1 } & 25.0 \% & 47.4 \% & -3.4 \% & 25.7 \% & 100 \% & & & & \\ \text { PL2 } & -24.7 \% & -48.1 \% & 4.1 \% & -23.6 \% & -99.4 \% & 100 \% & & & \\ \text { PL3 } & 17.0 \% & 37.5 \% & -6.6 \% & 15.7 \% & 89.7 \% & -88.3 \% & 100 \% & & \\ \text { PL4 } & 17.6 \% & 36.6 \% & -6.1 \% & 16.8 \% & 90.2 \% & -88.5 \% & 99.9 \% & 100 \% & & \\ \text { LM1 } & 20.7 \% & 44.7 \% & -6.4 \% & 17.6 \% & 96.9 \% & -97.4 \% & 87.5 \% & 87.2 \% & 100 \% & \\ \text { LM2 } & -16.6 \% & -16.6 \% & -9.2 \% & -27.5 \% & -6.1 \% & 6.1 \% & 8.7 \% & 6.1 \% & 14.0 \% & 100 \%\end{array}$

ITALY (2003 sample, obs. 71)

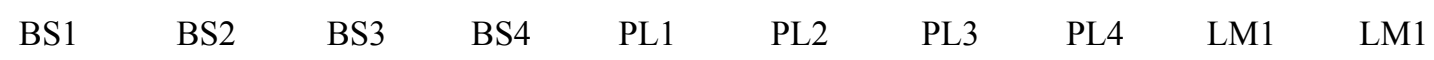

$\begin{array}{lrrrrrrrrrr}\text { BS1 } & 100 \% & & & & & & & & \\ \text { BS2 } & 97.7 \% & 100 \% & & & & & & & \\ \text { BS3 } & -0.4 \% & 0.3 \% & 100 \% & & & & & & \\ \text { BS4 } & 82.0 \% & 78.3 \% & 22.6 \% & 100 \% & & & & & \\ \text { PL1 } & 36.6 \% & 32.2 \% & -1.9 \% & 35.9 \% & 100 \% & & & & \\ \text { PL2 } & 45.4 \% & 39.6 \% & -7.0 \% & 32.1 \% & 47.1 \% & 100 \% & & & \\ \text { PL3 } & 1.5 \% & 0.7 \% & 19.7 \% & -3.9 \% & 38.2 \% & 14.5 \% & 100 \% & & \\ \text { PL4 } & 4.2 \% & 3.1 \% & 22.3 \% & -0.4 \% & 43.1 \% & 17.2 \% & 99.0 \% & 100 \% & & \\ \text { LM1 } & 13.0 \% & 10.4 \% & 9.0 \% & 2.4 \% & 41.9 \% & 30.0 \% & 59.8 \% & 61.9 \% & 100 \% & \\ \text { LM2 } & 9.3 \% & 7.4 \% & -10.3 \% & -8.0 \% & 38.3 \% & 37.7 \% & 52.6 \% & 54.9 \% & 79.6 \% & 100 \%\end{array}$

As one would expect, there is a positive association between BS1, BS2, BS4, PL1 and PL2, which are the key proxies for balance sheet and P\&L ratios of severance pay leverage. On the other hand, ratios measuring the relative importance of severance pay costs with respect to wage bill and personnel cost do not seem to be meaningfully associated with the other risk indicators, at least in the Italian sample. 


\subsection{Correlation with beta and volatility}

Before running multivariate regressions, the bivariate relationship between volatility (or beta) and severance pay risk exposure indicators was investigated using scatter plots with fitted using non-parametric local regression lines (lowess smoother). Figure 6.1 presents the results with BS1 which indicate some evidence of association with volatility and beta, especially for Italy and beta, but suggesting the hypothesis of a bell-shaped relationship where the marginal impact of severance pay exposure is higher for higher values of the BS1 ratio. Conversely, results for BS4 and PL1 (not shown but available upon request) are more mixed.

For Italy, where the number of companies is larger and enables us to meaningfully investigate trends over time, a 2-year volatility and beta panel was constructed by matching 2003 accounting disclosures with volatilities and betas calculated in November 2004 and 2002 financials with separately collected volatilities and betas calculated in October 2003. Local (kernel) regression results for beta in the two matched samples are displayed in Figure 6.2 and substantially confirm the pattern highlighted with 2003 wave data. 
Figure 6.1 Local Regression Lines (Lowess Smoother) of Volatility (1-year and 162 weeks) or Beta and BS1

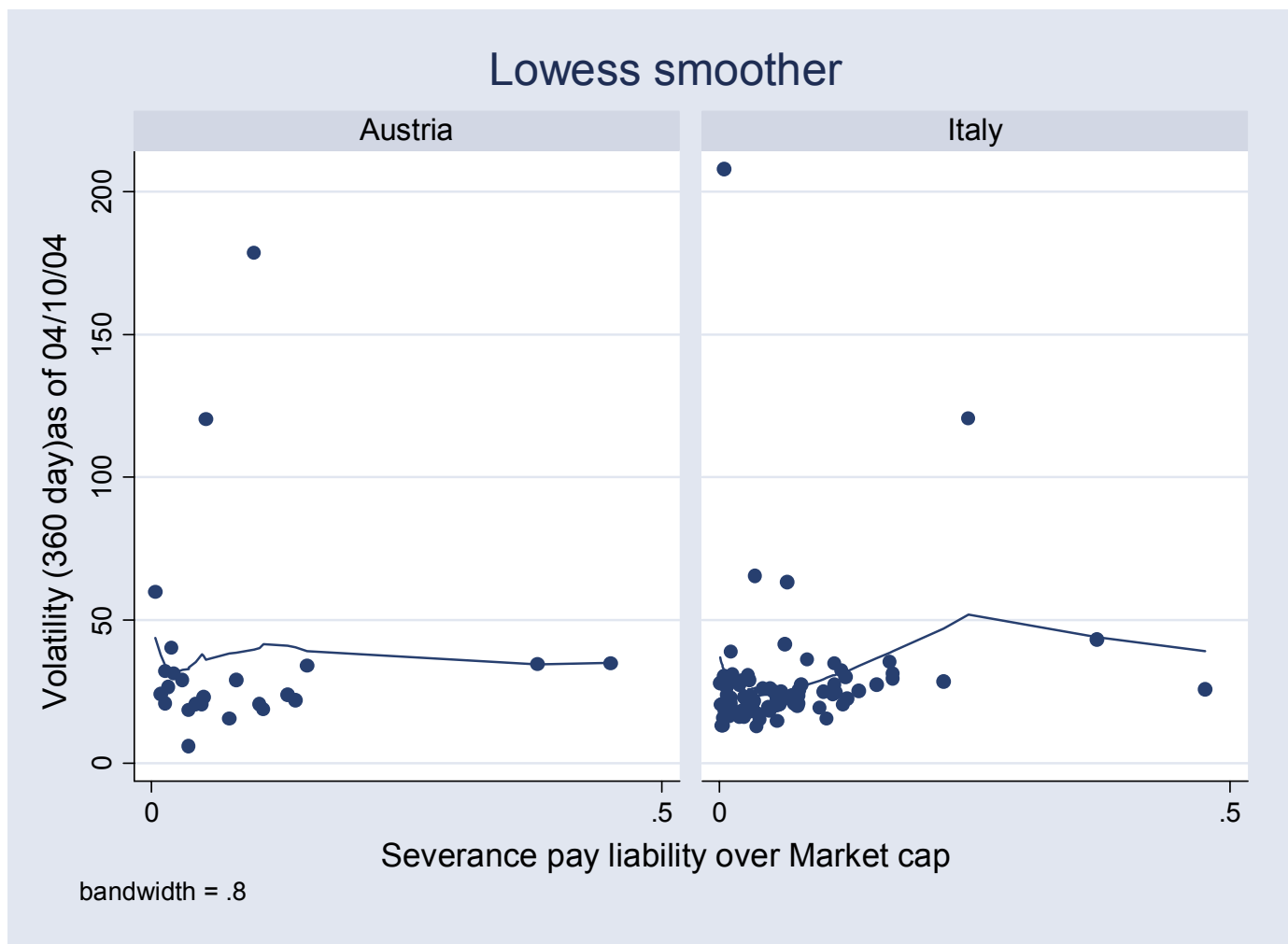

Note: $B S 1$ ratio capped at 1

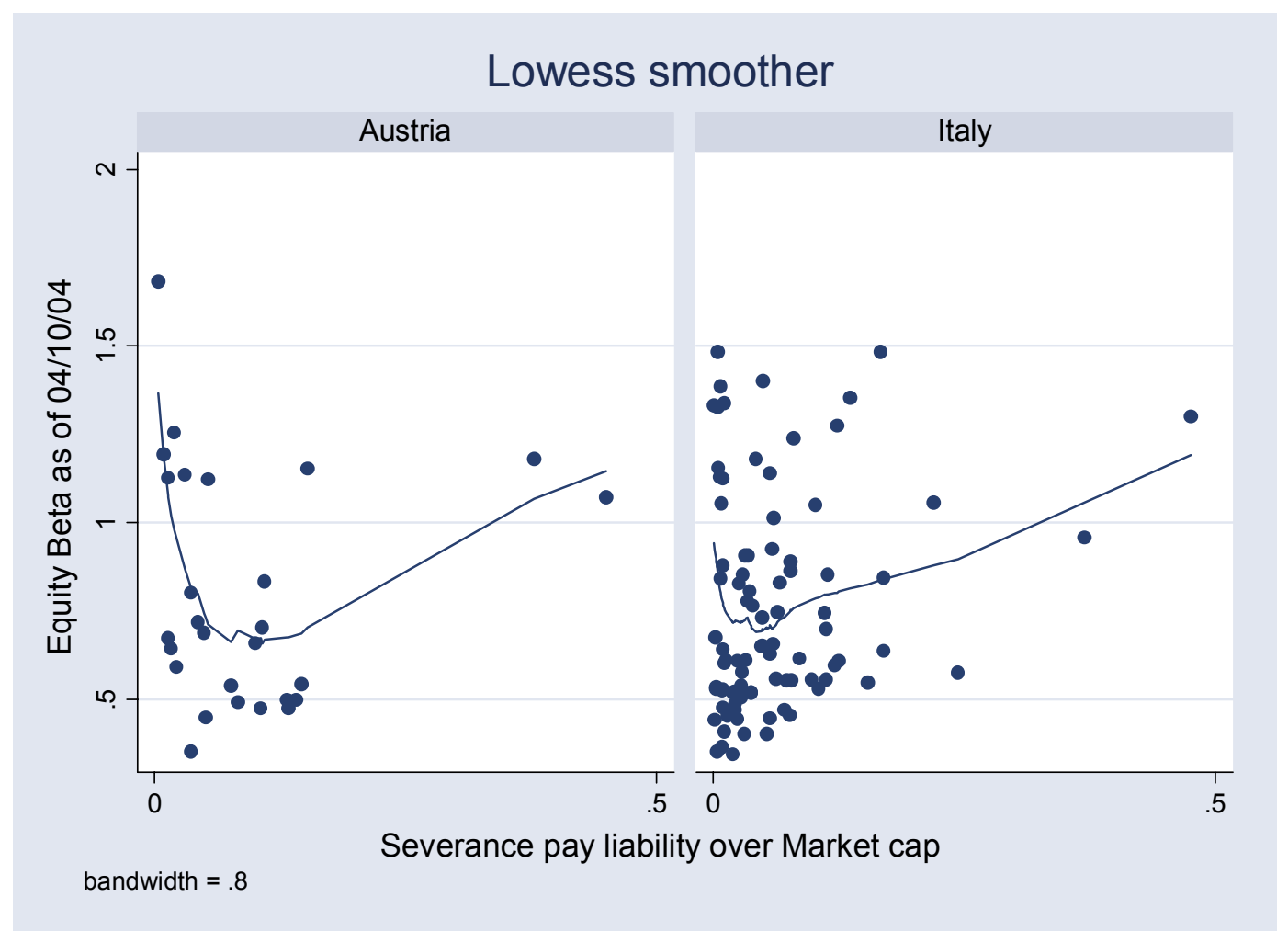

Note: BS1 ratio capped at 1 


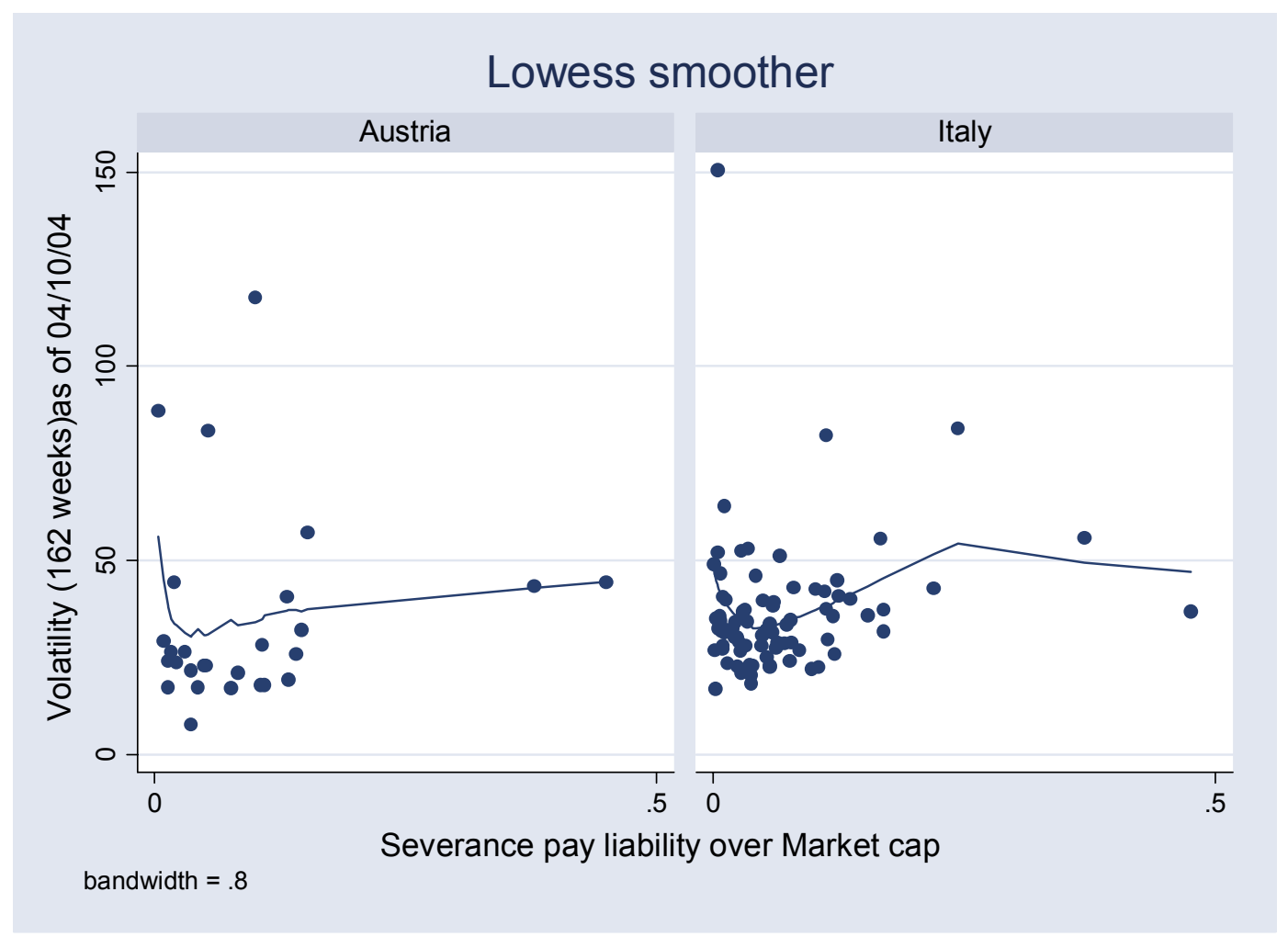

Note: $B S 1$ ratio capped at 1

Figure 6.2 Local Regression Lines (Lowess Smoother) of Volatility or Beta and BS1 in the Italian 2-year matched sample

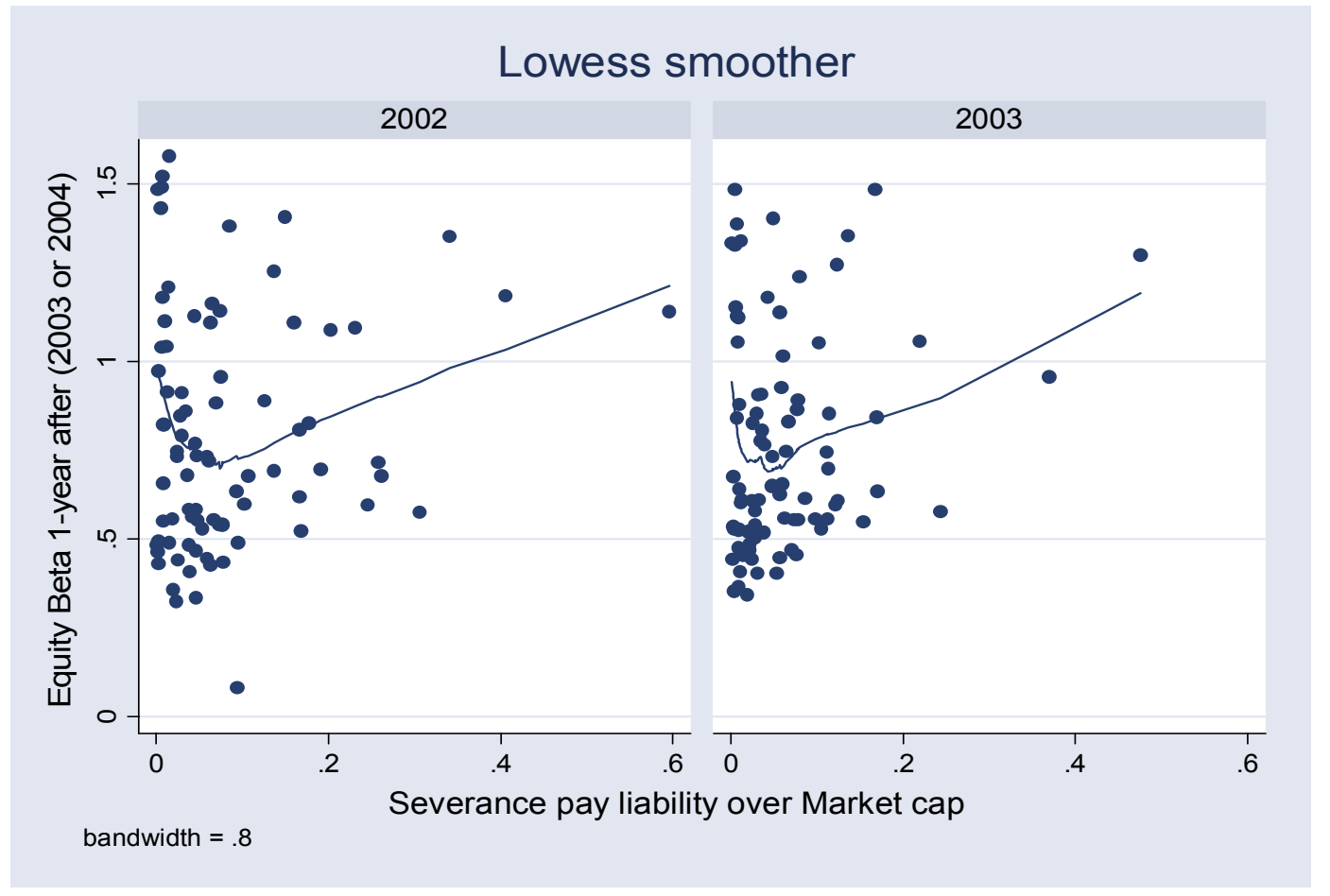

Note: BS1 ratio capped at 1 


\subsection{Regression results: Italy}

We present here selected results arising from multiple regression models to explain stock-specific volatility and market beta in function of severance pay risk exposure indicators. The results are presented here separately for Italy where the sample is large enough.

Table 6.2: Multiple regression models of market beta (Italy)

\begin{tabular}{|c|c|c|c|c|c|c|}
\hline Sample & Panel & Panel & 2003 & 2003 & 2003 & 2003 \\
\hline Dependent Variable & Beta & Beta & Beta & Beta & Beta & Beta \\
\hline Regression & $\begin{array}{c}\text { Random } \\
\text { Effects }\end{array}$ & $\begin{array}{l}\text { Random } \\
\text { Effects }\end{array}$ & $\begin{array}{c}\text { Least } \\
\text { Squares }\end{array}$ & $\begin{array}{l}\text { Quantile } \\
\text { Regression } \\
\text { (median) }\end{array}$ & $\begin{array}{c}\text { Least } \\
\text { Squares }\end{array}$ & $\begin{array}{c}\text { Least } \\
\text { Squares }\end{array}$ \\
\hline \multirow[t]{2}{*}{$\mathrm{BS} 1$} & 0.20 & 0.32 & -1.07 & 1.23 & -1.40 & 0.06 \\
\hline & $(0.02)$ & $(0.14)$ & $(0.47)$ & $(0.01)$ & $(0.39)$ & $(0.97)$ \\
\hline \multirow[t]{2}{*}{ BS1 (1-YEAR LAG) } & & & 2.06 & & 2.16 & 0.72 \\
\hline & & & $(0.03)$ & & $(0.01)$ & $(0.51)$ \\
\hline \multirow[t]{2}{*}{ BS1 (2-YEAR LAG) } & & & -1.88 & & -2.27 & -1.49 \\
\hline & & & $(0.11)$ & & $(0.07)$ & $(0.16)$ \\
\hline \multirow[t]{2}{*}{ RATED } & 0.17 & 0.16 & 0.15 & 0.19 & 0.18 & 0.13 \\
\hline & $(0.02)$ & $(0.02)$ & $(0.14)$ & $(0.11)$ & $(0.08)$ & $(0.19)$ \\
\hline $\begin{array}{l}\text { INDUSTRY } \\
\text { DUMMIES }\end{array}$ & Yes & Yes & Yes & Yes & Yes & Yes \\
\hline \multirow{2}{*}{ LEVERAGE } & & -0.01 & & & & -0.07 \\
\hline & & $(0.57)$ & & & & $(0.32)$ \\
\hline \multirow[t]{2}{*}{$\begin{array}{l}\text { LEVERAGE (1- } \\
\text { YEAR LAG) }\end{array}$} & & & & & & 0.12 \\
\hline & & & & & & $(0.06)$ \\
\hline \multirow[t]{2}{*}{$\begin{array}{l}\text { LEVERAGE (2- } \\
\text { YEAR LAG) }\end{array}$} & & & & & & -0.07 \\
\hline & & & & & & $(0.13)$ \\
\hline \multirow[t]{2}{*}{ PL1 } & & & & & 51.94 & \\
\hline & & & & & $(0.03)$ & \\
\hline \multirow[t]{2}{*}{ PL1 (1 YEAR LAG) } & & & & & -18.22 & \\
\hline & & & & & $(0.16)$ & \\
\hline \multirow[t]{2}{*}{ PL1 (1 YEAR LAG) } & & & & & -21.27 & \\
\hline & & & & & $(0.39)$ & \\
\hline \multirow[t]{2}{*}{ CONSTANT } & 0.54 & 0.55 & 0.65 & 0.53 & 0.61 & 0.67 \\
\hline & $(0.00)$ & $(0.00)$ & $(0.00)$ & $(0.01)$ & $(0.00)$ & $(0.00)$ \\
\hline \multirow[t]{2}{*}{$\begin{array}{l}\text { F TEST/WALD CHI } \\
\text { TEST }\end{array}$} & 29.50 & 28.05 & 4.50 & & 5.76 & 4.21 \\
\hline & $(0.00)$ & $(0.00)$ & $(0.00)$ & & $(0.00)$ & $(0.00)$ \\
\hline
\end{tabular}




\begin{tabular}{|l|c|c|c|c|c|c|}
\hline N. of OBS. & 174 & 171 & 71 & 90 & 63 & 71 \\
\hline R-SQUARED & $22.46 \%$ & $21.31 \%$ & $25.39 \%$ & $19.37 \%$ & $39.62 \%$ & $30.32 \%$ \\
\hline
\end{tabular}

Notes:

1. Reported standard errors (in parenthesis) are Newey-West robust standard errors

The results support the evidence of a pattern of association between market beta and severance pay exposure (Severance Pay Liability over Market Cap), both in the 2year matched panel and in the 2003 sample (if beta is taken with a 1-year lag). A similar patter arises if the BS1 ratio is replaced with PL1, while results are more mixed if the BS4 ratio is employed, which includes long-term debt in the denominator (not shown but available upon request).

The regressions included a dummy for whether a company is rated, which is positive and significant in the panel indicating that, other things equal, companies tapping international capital markets tend to have higher beta.

In the regressions with November 2004 beta as dependent variable the 1-year lagged value of the BS1 ratio is significant suggesting that other things being equal a $1 \%$ higher BS1 translates into a $2 \%$ greater beta after 1 year. Results are also robust if estimated with a quantile regression, which is more appropriate given non-normalities and outliers in the distributions. If the PL1 ratio is included in the multiple regression model, the results suggest that the ratio could have a separate predictive power of market beta. A regression with current and lagged values of BS1 and PL1 plus usual control factors (rating and industry effects) yield an R-square around 40\%.

Nevertheless, these results are not robust to the inclusion of the standard leverage ratio in the regression, mainly because there is some evidence of a pattern of association between leverage and BS1, as shown by Figure 6.3 (correlation is $50 \%$ in wave 2003), which leads to multicollinearity problems ${ }^{7}$. It is hard therefore to separate the effect of severance pay exposure from a more standard relationship between market risk and corporate leverage. 
Figure 6.2 Relationship between Leverage (Long Term Debt over Market Cap) and BS1 ratio: Local Regression Line (Lowess Smoother)

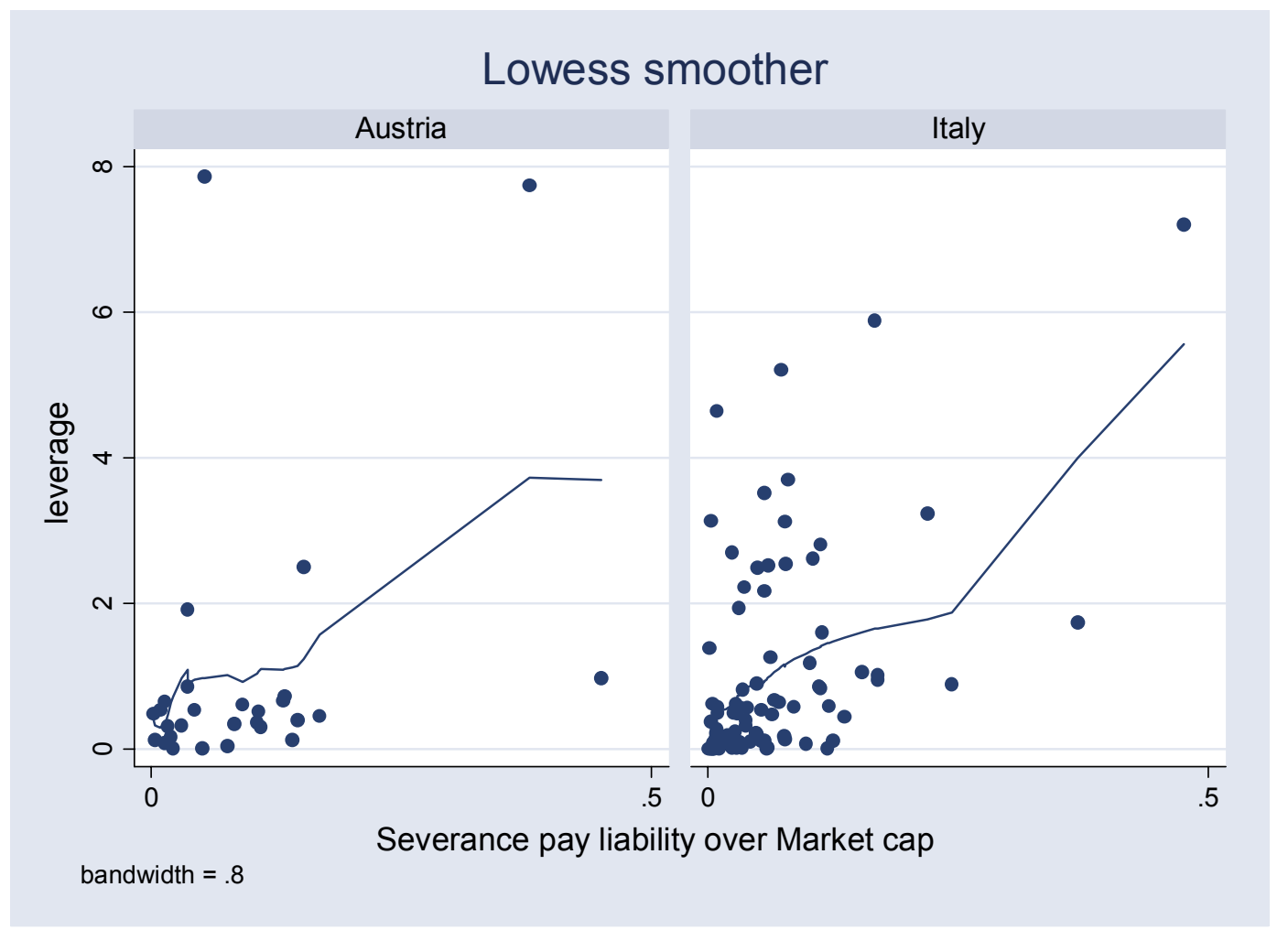

Note: $B S 1$ ratio capped at 1 , Leverage capped at 10

However, the picture is different when 1-year share price volatility is considered instead of market beta. Table 6.3 suggest no association between volatility and severance pay exposure and the results (not shown but available upon request) do not change if volatility is calculated over a different period (e.g. 162 weeks).

\footnotetext{
${ }^{7}$ All the previous regressions become insignificant with the inclusion of leverage
} 
Table 6.3: Multiple regression models of 360-days volatility (Italy)

\begin{tabular}{|l|c|c|}
\hline Sample & Panel & 2003 \\
\hline Dependent Variable & $\begin{array}{c}360 \text { Days } \\
\text { Volatility }\end{array}$ & $\begin{array}{c}360 \text { Days } \\
\text { Volatility }\end{array}$ \\
\hline Regression & $\begin{array}{c}\text { Random } \\
\text { Effects }\end{array}$ & $\begin{array}{c}\text { Least } \\
\text { Squares }\end{array}$ \\
\hline BS1 & 9.24 & 214.32 \\
\hline & $(0.12)$ & $(0.32)$ \\
\hline BS1 (1-YEAR LAG) & & 11.11 \\
\hline BS1 (2-YEAR LAG) & & $(0.86)$ \\
\hline & & -146.18 \\
\hline RATED & 4.29 & 2.59 \\
\hline & $(0.22)$ & $(0.75)$ \\
\hline INDUSTRY DUMMIES & Yes & Yes \\
\hline & & \\
\hline CONSTANT & 19.42 & 12.02 \\
\hline & $(0.00)$ & $(0.02)$ \\
\hline F TEST/WALD CHI TEST & 8.43 & 2.42 \\
\hline & $(0.39)$ & $(0.02)$ \\
\hline N. of OBS. & 176 & 72 \\
\hline R-SQUARED & $5.02 \%$ & $6.69 \%$ \\
\hline
\end{tabular}

Notes:

2. Reported standard errors (in parenthesis) are Newey-West robust standard errors

3. Results do not change meaningfully adding Beta as an additional control variable, but Beta is positive and significant in the panel

\subsection{Regression results: pooled sample}

This section replicates multiple regressions using a pooled sample where Austria companies are pooled together with the Italian companies. This approach assumes that severance liabilities can be compared across countries in spite of differences in how they are calculated as highlighted in Section 3. In this context we also investigate whether other severance pay exposure indicators such as PL1 have a separate predictive power of market beta. 
Table 6.2: Multiple regression models of market beta (pooled sample)

\begin{tabular}{|c|c|c|c|c|}
\hline Sample & Pooled & Pooled & Pooled & Pooled \\
\hline Dependent Variable & Beta & Beta & Beta & $\begin{array}{l}360 \text { Days } \\
\text { Volatility }\end{array}$ \\
\hline Regression & $\begin{array}{c}\text { Least } \\
\text { Squares }\end{array}$ & $\begin{array}{c}\text { Least } \\
\text { Squares }\end{array}$ & $\begin{array}{c}\text { Least } \\
\text { Squares }\end{array}$ & $\begin{array}{c}\text { Least } \\
\text { Squares }\end{array}$ \\
\hline \multirow[t]{2}{*}{ BS1 } & -0.08 & & & 81.04 \\
\hline & $(0.95)$ & & & $(0.48)$ \\
\hline \multirow[t]{2}{*}{ BS1 (1-YEAR LAG) } & 2.01 & & & 67.63 \\
\hline & $(0.01)$ & & & $(0.22)$ \\
\hline \multirow[t]{2}{*}{ BS1 (2-YEAR LAG) } & -2.54 & & & -153.01 \\
\hline & $(0.01)$ & & & $(0.04)$ \\
\hline \multirow[t]{2}{*}{$\begin{array}{l}\text { BS1 (1 YEAR } \\
\text { DIFFERENCE) }\end{array}$} & & 0.41 & 0.30 & \\
\hline & & $(0.00)$ & $(0.40)$ & \\
\hline \multirow[t]{2}{*}{$\begin{array}{l}\text { LEVERAGE (1 YEAR } \\
\text { DIFFERENCE) }\end{array}$} & & & 0.01 & \\
\hline & & & $(0.76)$ & \\
\hline \multirow[t]{2}{*}{ RATED } & 0.16 & 0.20 & 0.19 & -0.96 \\
\hline & $(0.05)$ & $(0.00)$ & $(0.00)$ & $(0.89)$ \\
\hline \multirow[t]{2}{*}{ AUSTRIA DUMMY } & 0.07 & 0.04 & 0.06 & 6.27 \\
\hline & $(0.35)$ & $(0.41)$ & $(0.27)$ & $(0.35)$ \\
\hline INDUSTRY DUMMIES & Yes & Yes & Yes & Yes \\
\hline \multirow[t]{2}{*}{ CONSTANT } & 0.60 & 0.54 & 0.55 & 15.86 \\
\hline & $(0.00)$ & $(0.00)$ & $(0.00)$ & $(0.00)$ \\
\hline \multirow[t]{2}{*}{ F TEST/WALD CHI TEST } & 2.62 & 6.76 & 6.31 & 4.11 \\
\hline & $(0.01)$ & $(0.00)$ & $(0.00)$ & $(0.01)$ \\
\hline N. of OBS. & 99 & 218 & 212 & 96 \\
\hline R-SQUARED & $21.58 \%$ & $16.34 \%$ & $16.14 \%$ & $6.08 \%$ \\
\hline
\end{tabular}

Notes:

1. Reported standard errors (in parenthesis) are Newey-West robust standard errors

The results substantially confirm what highlighted in the previous section showing some evidence of a pattern of association with beta, but not volatility. In particular, 1year lagged severance pay exposure has a positive impact on beta while the residual effect of 2-year lagged exposure is negative, suggesting that the market recognises not only the level but also changes in severance pay exposure. The model was also estimated using the first difference of the BS1 ratio as a predictor and the results 
suggest that, other things being equal, a $1 \%$ increase in the ratio leads to a $0.40 \%$ increase in volatility ${ }^{8}$.

However, as expected, results are again not robust to the inclusion of Leverage, both using the first difference of BS1 or the level of BS1 and its lagged values as predictors.(the latter is not shown but available upon request)

\section{Conclusions}

Severance pay systems are one of the most widespread employee benefits in the world. Severance pay is necessarily a debt of the employer and hence needs to be assessed as part of corporate finance. Severance pay systems have been criticised on the grounds they have negative impact on corporate value and economic efficiency yet there has been no effort we are aware of to examine this impact empirically.

Theory suggests higher severance pay as a debt of the employer should lead to higher beta and volatility. This paper examines these relationships empirically for Italy and Austria. We find only limited support for the hypothesis that the market takes into account severance pay liabilities in assessing the value of firms. There is in fact some evidence of a pattern of association with beta, which is not robust to the inclusion of corporate leverage as a control factor, and no significant evidence of association with volatility.

\footnotetext{
${ }^{8}$ This result is not driven by an association between changes in market cap and the level of volatility, but by the change in severance pay liabilities. The regression was in fact replicated using the first difference of market cap and the first difference of severance pay liabilities: only severance liabilities stay significant (not shown but available upon request)
} 


\section{References}

Bodie, Zvi (1985), Corporate Pension Policy: An Empirical Investigation, Financial Analysts Journal, 41(5), 10-16.

Bulow, Jeremy; Morck, Randall and Summers, Lawrence (1987), How Does the Market Value Unfunded Pension Liabilities? In Zvi Bodie, John Shoven and David

Wise (eds), Issues in Pension Economics (Chicago: Univ of Chicago Press), 81-104.

Carroll, Thomas J. and Niehaus, Greg (1998), Pension Plan Funding and Corporate Debt Ratings, Journal of Risk and Insurance, 65(3), Sept. 1998, 427-443.

Feldstein, Martin and Seligman, Stephanie (1981), Pension Funding, Share Prices and National Savings, Journal of Finance, 36, 801-24.

Jin, Li; Merton, Robert C. and Bodie, Zvi (2004), Do a Firm's Equity Returns Reflect the Risk if Its Pension Plan, unpublished paper

IASB (1998), International Accounting Standard. Employee Benefits

Micocci, Marco (2001), La valutazione attuariale del TFR secondo il principio contabile internazionale IAS 19, Università di Cagliari Working Paper

Modigliani, Franco and Merton H. Miller (1958): Corporate Pension Policy: An Empirical Investigation, Financial Analysts Journal, 41(5), pp. 10-16

Mittelstaedt, Fred and Warshawsky, Mark (1993), The Impact of Liabilities for Retiree Health Benefits on Share Prices, Journal of Risk and Insurance, 60(1), 1993, $13-35$.

Watson Wyatt (2004a), Benefits Report Europe. Watson Wyatt Data Services.

Watson Wyatt (2004b), Employment Terms and Conditions: Europe. Watson Wyatt Data Services. 